\title{
Influence of liposomal drug on the intensity of proteins oxide modification processes in subclinical mastitis of cows
}

\author{
valentinachepurna70@gmail.com \\ 1Podillia State University, \\ 13 Shevchenko str., Kamianets-Podilskyi, Khmelnytsk region, 32316, Ukraine \\ 2Institute of Animal Biology NAAS, \\ 38 V. Stus str., Lviv, 79034, Ukraine \\ ${ }^{3}$ Lviv National Agrarian University, \\ 1 Volodymyr Velykyi str., Dubliany, Zhovkva district, Lviv region, 80381, Ukraine
}

V. A. Chepurna ${ }^{1}$, T. M. Suprovych ${ }^{1}$, O. I. Vishchur², V. P. Mizik¹, I. Ye. Solovodzinska ${ }^{3}$

The article contains the experimental studies of the liposomal drug based on plant raw materials - hypericum (Hypericum perforatum $\mathrm{L}$.) effect on the intensity of oxidative modification of proteins (OMP) in the blood and milk of cows with subclinical mastitis. Studies have shown that cows with signs of subclinical form of mastitis in the serum have an increase in the content of aldehyde-derived $\mathrm{OMP}_{370}$ and ketone-derived $\mathrm{OMP}_{430}$, respectively, 1.3 and 1.2 times relative to similar indicators in healthy animals. In the milk of sick cows, the content of derivatives $\mathrm{OMP}_{370}$ and $\mathrm{OMP}_{430}$ was 1.99 and 2.29 times higher, respectively, than in animals of the control group. At the beginning of the study sick cows' milk was recorded a significantly low value of the activity of the enzymatic link of antioxidant protection - superoxide dismutase. At the same time, a 2.6-fold $(P<0.001)$ increase in the number of somatic cells was noted compared to their number in the milk of clinically healthy cows. Intracisternal injection of liposomal drug to cows caused a decrease in the intensity of oxidative processes. In the blood of sick cows the content of aldehyde derivatives $\mathrm{OMP}_{370}$ on the $9^{\text {th }}$ day of the experiment was $23.1 \%(\mathrm{P}<0.05)$ less than before the drug, and in milk the content of $\mathrm{OMP}_{370}$ decreased by $61,8 \%(P<0.01)$. Similar changes were observed with respect to the level of ketone derivatives. In particular, on the 9th day of the experiment, the content of $\mathrm{OMP}_{430}$ decreased by $11.7 \%(\mathrm{P}<0.05)$ compared with its value in the blood of sick animals before the introduction of the study drug, and in milk it decreased by $64.2 \%(P<0.01)$. During the treatment on the $9^{\text {th }}$ day of the experiment, the number of somatic cells in milk decreased by $41.8 \%(P<0.01)$. In the course of treatment on the $3^{\text {rd }}$ and $9^{\text {th }}$ day there was a tendency to increase superoxide dismutase activity in the milk of sick cows compared with the beginning of the experiment. Thus, intracisternal injection of liposomal drug to cows with subclinical mastitis leads to a decrease in aldehyde and ketone derivatives of proteins oxidative modification in serum and milk. At the same time, an increase in the activity of the enzymatic link of antioxidant protection and a decrease in the number of somatic cells in the milk of cows were recorded.

Key words: cows, subclinical mastitis, somatic cells, oxidative modification of proteins, liposomal drug

The problem of cattle mastitis in Ukraine is defined by researchers as the main issue of the livestock industry. Because ofthe widespread spread of udder diseases among cows, dairy farming and processing industry suffer significant economic losses due to reduced dairy productivity, deteriorating quality of milk and dairy products [11].
Milk undergoes significant physicochemical changes during mastitis which seriously affects the technological processes of its processing into dairy products, especially reducing their quality [10].

Any pathological processes in the body are accompanied by the activation of free radical processes in the tissues and organs of a sick animal. Free radicals in- 
clude compounds that contain unpaired electrons and have a much greater reactivity to their non-radical counterparts $[8,13]$. All functionally important free radicals that are formed in the body contain oxygen.

These compounds are combined by the term "reactive oxygen species" (ROS). The main forms of ROS generated in a living organism are: superoxide radical, hydroxyl radical, nitric oxide, peroxyl radical, hydrogen peroxide and others. The main forms of ROS are primarily normal components of cellular metabolism and perform certain biological functions. Their reactive aggressiveness is restrained by a powerful antioxidant system. However, with the development of pathological processes, this balance is disturbed in the direction of uncontrolled synthesis of ROS, which ends with the formation of oxidative stress.

It is established that under conditions of oxidative stress and excessive ROS generation, the processes of proteins uncontrolled modification develop, causing protein fragmentation, their denaturation, as well as the formation of primary amino acid radicals, which then enter into secondary interaction with neighboring amino acid residues. All these in totalcreate a difficult situation of the damaging effect of ROS on protein macromolecules. This leads to the loss of proteins biological activity and disruption of metabolic, in particular regenerative processes [4].

In view of the various functions of proteins in animals, as well as taking into account the data of literature sources on the primary damage of protein molecules ROS $[1,6]$, the study of peroxidation processes, especially proteins, is important.

Destruction of cellular proteins in the process of oxidative modification of proteins (OMP) in proteosomes leads to cell death [12], i.e. a direct link between the processes of OMP and many diseases is established [15]. It is believed that the level of OMP compared to the level of lipid peroxidation (LPO) is a more informative marker of the presence of oxidative stress in the body [16].

Both LPO and OMP are normal functional processes in the body that involve vital functions. Moreover, the processes of OMP are largely associated with protective and adaptive reactions of the organism. However, the violation of protective reactions leads to a decrease in the body's resistance. Thus, oxidative modification of proteins plays a key role in the molecular mechanisms of oxidative stress, which is an important part of many pathological processes in the body in various diseases and requires further study. The aim of the study was to determine the effect of liposomal drug on the intensity of oxidative modification of proteins in blood and milk, as well as on superoxide dismutase activity in the milk of cows with subclinical mastitis.

\section{Materials and Methods}

We hereby declare all ethical standards have been respected in the preparation of the submitted article. Permission to use animals approved by the State
Agrarian and Engineering University in Podillya in accordance with the European Convention for the Protection of Vertebrate Animals used for experimental and other scientific purposes.

Experimental studies were conducted at LLC "LanyVinkovechchyna" (Khmelnytsky region) on cows which were divided into two groups: control (healthy animals) and experimental, 7 animals in each group, based on the analogue's principle. The experimental group was formed from animals with subclinical mastitis (CM) [2].

Subclinical mastitis was determined by the reaction of secretion from each quarter on a milk control plate with $2 \%$ solution of mastidine. Cows of the experimental group in the affected quarters of the udder were injected intracisternally liposomal drug three times with an interval of 24 hours - the first day $10 \mathrm{~cm}^{3}$, the next two days $-5 \mathrm{~cm}^{3}$. Before the drug injection cowswere milked by hand, the teats were disinfected. After drug injection, the udder was massaged from the bottom to the top for its even distribution. The cows were transferred to manual milking. Half of the therapeutic dose was prophylactically injected to healthy quarters of the udder.

A liposomal drug made on the basis of plant raw materials is an antibacterial preparation developed in the laboratory of immunology of the Institute of Animal Biology NAAS. The composition of the drug: novoimanin - extract from Hypericum perforatum L., vitamins $A, D_{3}, E$, lecithin, twin. The drug is active against gram-positive bacteria including Streptococcus pyogenes and Streptococcus agalactiae. The anti-inflammatory effect is due to the presence of flavonoids in the drug. It has the ability to heal the wound surface and stimulates tissue regeneration [3].

For biochemical studies, cows were bled from the jugular vein before morning feeding on the $1^{\text {st }}$ day (before drug injection), on the $3^{\text {rd }}$ and $9^{\text {th }}$ day after its use.

The level of oxidative damage of proteins was evaluated by the content of aldehyde $\left(\mathrm{OMP}_{370}\right)$ and ketone derivatives $\left(\mathrm{OMP}_{430}\right)$ of oxidative modification of proteins in reaction with 2,4-dinitrophenylhydrazine [7]. Superoxidedismudase activity in cows' milk was determined by the method described by E. E. Dubinina [5].

To control the recovery of milk quality, we used the analyzer AMB 1-02 designed to measure the conditional milk stickiness and calculate the concentration of somatic cells in it [9]. Statistical data processing was performed using Microsoft Excel software.

\section{Results and Discussion}

Free radicals with high reactivity are formed as a result of metabolic transformations of substances under the action of pathogenic factors in the body of animals. Formed in the body, they interact with the components of the cell, cause damage to cell membranes, thus accompanying the development of the pathological process. Protein degradation is a more reliable mark- 
er of oxidative tissue damage than lipid peroxidation products (LPO) because protein oxidative modification (OMP) derivatives are more stable.

As a result of our research, it was found that before treatment animals with signs of mastitis have blood content of oxidative modification of proteins, namely: aldehyde-derived $\mathrm{OMP}_{370}$ and ketone-derived $\mathrm{OMP}_{430}$ that is 1.3 and 1.2 times higher than the blood of control cows groups (table 1). The introduction of the studied liposomal drug caused a decrease in the intensity of oxidative processes, as indicated by a decrease of $23.1 \%(P<0.05)$ of aldehyde derivatives $\mathrm{OMP}_{370}$ in the experimental group cows blood on the $9^{\text {th }}$ day of the experiment than before the introduction of liposomal drug. Similar changes were observed with respect to the level of ketone derivatives. Thus, on the $9^{\text {th }}$ day of the experiment, the content of $\mathrm{OMP}_{430}$ decreased by $11.7 \%$ compared with the value of this indicator in the blood of sick animals before the introduction of the study drug $(P<0.05)$. These data indicate the inhibitory effect of the components of the studied liposomal drug on the intensity of oxidative modification of proteins in the blood of cows with subclinical mastitis [14].

Table 1. The content of aldehyde and ketone starting oxidative modification of proteins in the serum of cows $(M \pm m ; n=7)$

\begin{tabular}{l|c|c|c|c}
\multicolumn{1}{|c|}{ Parameters } & Control group & before treatment & $3^{\text {rd }}$ day of treatment & $\begin{array}{c}9^{\text {th }} \text { day from the beginning } \\
\text { of treatment }\end{array}$ \\
\hline $\begin{array}{l}\mathrm{OMP}_{370}, \\
\mathrm{nmol} / \mathrm{mg} \text { protein }\end{array}$ & $21.34 \pm 1.64$ & $27.46 \pm 1.23^{* *}$ & $24.53 \pm 2.05$ & $21.45 \pm 1.96^{*}$ \\
\hline $\begin{array}{l}\mathrm{OMP}_{430}, \\
\mathrm{nmol} / \mathrm{mg} \text { protein }\end{array}$ & $32.18 \pm 1.32$ & $38.65 \pm 2.08^{* *}$ & $37.6 \pm 2.06$ & $32.92 \pm 2.35^{*}$ \\
\hline
\end{tabular}

Note. ${ }^{*}-\mathrm{P}<0.05-$ probability in animals of this group compared to the indicators before drug injection ( $1^{\text {st }}$ day of the experiment); ${ }^{* *}-\mathrm{P}<0.05-$ the difference is significant compared to the control group data.

Research has shown that before treatment cows with signs of mastitis have the content of derivatives $\mathrm{OMP}_{370}$ and $\mathrm{OMP}_{430}$ in milk 1.99 and 2.29 times higher compared with similar indicators of cows in the control group (table 2).

The content of both aldehyde and ketone derivatives of oxidative modification of proteins in cows' milk probably decreased in the dynamics of treatment, which is also an important diagnostic indicator of normalization of the intensity of oxidation processes and confirms the effectiveness of the study drug. Thus, the content of aldehyde derivatives $\mathrm{OMP}_{370}$ in the milk of the experimental group cows on the $3^{\text {rd }}$ and $9^{\text {th }}$ day of the experiment was 36.8 and $61.8 \%(P<0.01)$, respectively, less than before the drug injection. Similar changes were observed with respect to the level of ketone derivatives. In particular, on the $3^{\text {rd }}$ day of the experiment, the content of $\mathrm{OMP}_{430}$ in milk decreased by $40.6 \%$, and on the $9^{\text {th }}$ - by $64.2 \%$ $(P<0.01)$ compared with the value of this indicator in sick animals before the introduction of the study drug.

On the $3^{\text {rd }}$ and $9^{\text {th }}$ day during treatment, there is a tendency to increase superoxide dismutase activity in the milk of the experimental group animals compared with the indicator at the beginning of the experiment. The obtained results confirm that the components of the drug cause a regulatory effect on the intensity of oxidation and maintenance of pro- and antioxidant balance in the body of sick cows.

Table 2. The content of derivatives of oxidative modification of proteins and superoxide dismutase activity in cow's milk (M $\pm m$; $n=7)$

\begin{tabular}{|c|c|c|c|c|}
\hline \multirow[b]{2}{*}{ Parameters } & \multirow[b]{2}{*}{ Control group } & \multicolumn{3}{|c|}{ Experimental group } \\
\hline & & before treatment & $3^{\text {rd }}$ day of treatment & $\begin{array}{l}9^{\text {th }} \text { day from the beginning } \\
\text { of treatment }\end{array}$ \\
\hline $\begin{array}{l}\mathrm{OMP}_{370} \\
\mathrm{nmol} / \mathrm{mg} \text { protein }\end{array}$ & $7.78 \pm 1.84$ & $15.47 \pm 2.25^{\star \star}$ & $10.12 \pm 1.54$ & $6.25 \pm 1.16^{*}$ \\
\hline $\begin{array}{l}\mathrm{OMP}_{430} \\
\mathrm{nmol} / \mathrm{mg} \text { protein }\end{array}$ & $6.14 \pm 1.72$ & $14.06 \pm 2.08^{* *}$ & $8.65 \pm 1.43$ & $5.32 \pm 0.96^{*}$ \\
\hline $\begin{array}{l}\text { SOD, } \\
\text { unit of action } / \mathrm{mg} \min \text {. }\end{array}$ & $11.96 \pm 1.86$ & $11.84 \pm 2.34$ & $12.34 \pm 1.65$ & $13.47 \pm 1.85$ \\
\hline
\end{tabular}

Note. In this and the next table * $-\mathrm{P}<0.01-$ probability in animals of this group compared to the indicators before drug injection ( $1^{\text {st }}$ day of the experiment); ${ }^{* *}-P<0.001-$ the difference is significant compared to the control group data. 
Before treatment a significant increase in the number of somatic cells of 2.6 times $(P<0.001)$ is observed in the milk of the experimental animals group, compared with clinically healthy animals, which is associated with the subclinical form of mastitis (table 3). The introduction of the studied liposomal drug revealed a decrease in the number of somatic cells from the third day of treatment, and on the $9^{\text {th }}$ day of the experiment the number of somatic cells in the secretion of the mammary gland of the experimental group cows was lower by $41.8 \%$ $(P<0.01)$ than in the beginning of the experiment, and differences compared to animals in the control group were not significant. These data indicate a normalizing effect of the study drug components on the content of somatic cells in the milk of cows suffering from a subclinical form of mastitis.

Table 3. The content of somatic cells in the milk of cows $(M \pm m ; n=7)$

\begin{tabular}{|c|c|c|c|c|}
\hline \multirow[b]{2}{*}{ Parameters } & \multirow[b]{2}{*}{ Control group } & \multicolumn{3}{|c|}{ Experimental group } \\
\hline & & before treatment & $3^{\text {rd }}$ day of treatment & $\begin{array}{l}9^{\text {th }} \text { day from the beginning } \\
\text { of treatment }\end{array}$ \\
\hline $\begin{array}{l}\mathrm{SC} \text {, } \\
\text { thousand } / \mathrm{cm}^{3}\end{array}$ & $259.3 \pm 40.05$ & $667.9 \pm 64.9^{\star \star}$ & $573 / 7 \pm 52 / 08^{\star *}$ & $388 / 7 \pm 44 / 97^{*}$ \\
\hline
\end{tabular}

Thus, the use of liposomal drug contributed to a prolonged decrease in the intensity of oxidative processes, as well as the number of somatic cells in milk, due to both normalizing and stimulating effect of drug components on the activity of these protective mechanisms in cows suffering from subclinical mastitis.

\section{Conclusion}

Intracisternal injection of the studied liposomal drug to animals led to a decrease in the content of products of oxidative modification of proteins $(P<0.05-0.01)$. At the same time, the use of the drug caused a decrease in the number of somatic cells in the milk of cows by $41.8 \%$ $(P<0.01)$ with a simultaneous increase in superoxide dismutase activity compared to pre-treatment values.

\section{Prospects for Further Research}

It is planned to conduct a comprehensive functional study of immunocompetent cells, under the conditions of using a new complex liposomal drug in the treatment of cows with a clinical form of mastitis.

1. Bhattacharyya J, Chowdhury TD, Datta AG. Effect of endotoxin on protein degradation and lipid peroxidation of erythrocytes. J. Physiol. Pharmacol. 1999; 50 (2): 321-326. PMID: 10424726.

2. Chepurna V, Suprovych T, Vishchur O, Mizyk V. Condition of Tand B-cellular links of immunity in cows, the sick subclinic form of mastitis, when using a liposomal drug. Agr. Bull. the Black Sea Littoral. 2020; 96: 44-51. Available at: https://abbsl.osau. edu.ua/index.php/visnuk/article/view/126 (in Ukrainian)

3. Chepurna VA, Suprovych TM, Vishchur OI, Mizik VP. System of antioxidant protection in cows suffering from subclinical form of mastitis with the use of liposomal preparation. Sci. Tech. Bull. SCIVP Vet. Med. Prod. Feed Add. 2019; 20 (1): 117-122. Available at: http://www.scivp.Iviv.ua/images/files/Naukovo_tekhnichnyy_ byuleten/2019_20_1/20.pdf (in Ukrainian)
4. Denysenko O. Oxidative modification of proteins as a factor in the pathogenesis of allergodermatoses. Ukr. J. Dermatol. Venerol. Cosmetol. 2004; 1 (12): 23-26. (in Ukrainian)

5. Dubinina E, Salnikov L, Efimova L. Activity and isoenzyme spectrum of superoxide dismutase of erythrocytes and human blood plasma. Lab. Sci. 1983; 10: 30-33. (in Russian)

6. Karimov I. Oxidative modification of proteins and lipid peroxidation in the development of metabolic intoxication in pathology. Lab. Diagnost. 2005; 1 (31): 7-13. (in Ukrainian)

7. Levine RL, Garland D, Oliver CN, Amici A, Climent I, Lenz AG, Ahn BW, Shaltiel S, Stadtman ER. Determination of carbonyl content in oxidatively modified proteins. Method. Enzymol. 1990; 186: 464-478. DOI: 10.1016/0076-6879(90)86141-H.

8. Meshchishen I, Polliovyi V. Mechanism of oxidative modification of proteins. Bukovinian Med. Herald. 1999; 3 (1): 196-205. (in Ukrainian)

9. Milk and dairy products - Methods of microbiological control. DSTU 7357:2013. National standard of Ukraine. Kyiv, 2014. (in Ukrainian)

10. Murska S. Modern scientific approach for quality assurance and milk products without develop safe antibiotics to treat mastitis cows patients. Sci. Bull. LNUVMBT S. Z. Gzhytsky. Series Vet. Sci. 2016; 18 (65): 205-220. Available at: https://nvlvet.com.ua/ index.php/journal/article/view/74 (in Ukrainian)

11. Panevnyk V, Suprovych T. Etiological factors mastitis cows Ukrainian black-pied dairy breed. Sci. Bull. the LNUVMBT S. Z. Gzhytsky. Series Vet. Sci. 2016; 18 (70): 191-195. DOI: 10.15421/nvlvet7046. (in Ukrainian)

12. Poppek D, Grune T. Proteasomal defense of oxidative protein modifications. Antiox. Redox Signaling. 2006; 8 (1-2): 173-184. DOI: 10.1089/ars.2006.8.173.

13. Riabov G, Azizov Y, Dorokhov S. Oxidative modification of blood plasma proteins of patients in critical conditions. Anesthesiol. Resuscitation. 2000; 2: 72-75. (in Russian)

14. Sobko G, Broda O, Vishchur O, Kurtyak B. Influence of "Antymast" on the system of antioxidant defense of cows with subclinical form of mastitis. Sci. Bull. the LNUVMBT S. Z. Gzhytsky. Series Vet. Sci. 2016; 18 (65): 158-163. Available at: https://nvlvet. com.ua/index.php/journal/article/view/64 (in Ukrainian)

15. Stadtmann E. Role of oxidized amino acids in protein breakdown and stability. Method. Enzymol. 1995; 258: 379-393. DOI: 10.1016/0076-6879(95)58057-3.

16. Tiana L, Caib Q, Wei $H$. Alterations of antioxidant enzymes and oxidative damage to macromolecules in different organs of rats during aging. Free Rad. Biol. Med. 1998; 24 (9): 1477-1484. DOI: 10.1016/S0891-5849(98)00025-2. 


\title{
Вплив ліпосомального препарату на інтенсивність процесів окисної модифрікації протеїнів за субклінічного маститу корів
}

\author{
В. А. Чепурна 1 , Т. М. Супрович1, О. І. Вішур², В. П. Мізик', І. Є. Соловодзінська \\ valentinachepurna70@gmail.com \\ 1Подільський державний аграрно-технічний університет, \\ вул. Шевченка, 13, м. Кам'янець-Подільський, Хмельницька обл., 32316, Україна \\ ${ }^{2}$ Інститут біології тварин НААН, \\ вул. В. Стуса, 38, м. Львів, 79034, Україна \\ ЗЛьвівський національний аграрний університет, \\ вул. Володимира Великого, 1, м. Дубляни, Жовківський р-н, Львівська обл., 80381, Україна
}

Наведені результати експериментальних досліджень впливу ліпосомального препарату, виготовленого на основі рослинної сировини, звіробою продірявленого (Hypericum perforatum L.), на інтенсивність процесів окисної модифікації протеїнів (ОМП) у крові та молоці корів, хворих на субклінічну форму маститу. Дослідження показали, що у корів з ознаками субклінічної форми маститу в сироватці крові констатовано підвищення вмісту альдегідопохідних ОМП з7о кетонопохідних ОМП $_{430}-$ відповідно, в 1,3 і 1,2 раза щодо аналогічних показників у здорових тварин. При цьому у молоці хворих корів вміст похідних ОМП та ОМП 430 був в 1,99 і 2,29 раза більший, ніж у тварин контрольної групи. На початку дослідження у молоці хворих корів зафріксовано вірогідно низьке значення показника активності ензимної ланки антиоксидантного захисту - супероксиддисмутази. Водночас констатовано збільшення у 2,6 раза $(\mathrm{P}<0,001)$ кількості соматичних клітин порівняно з їх кількістю у молоці клінічно здорових корів. Інтрацистернальне введення коровам ліпосомального препарату спричиняло зниження інтенсивності окисних процесів. У крові хворих корів вміст альдегідних похідних ОМП ший, ніж до початку введення препарату; в молоці вмістОМП 370 зменшився на $61,8 \%(P<0,01)$. Аналогічні зміни констатовано щодо рівня кетонових похідних. Зокрема, на 9-ту добу експерименту вміст ОМП значенням у крові хворих тварин до введення досліджуваного препарату, а в молоці став меншим на $64,2 \%$ (P<0,01). 3a проведеного лікування на 9-ту добу експерименту кількість соматичних клітин у молоці знизилась на 41,8\% відносно початку досліду $(P<0,01)$. У процесі лікування на 3- і 9-ту доби виявлено тенденцію до підвищення супероксиддисмутазної активності у молоці хворих корів порівняно з показниками на початку досліду. Отже, інтрацистернальне введення ліпосомального препарату коровам, хворим на субклінічну форму маститу, призводить до зниження альдегідних та кетонових похідних окисної модифікації протеїнів у сироватці крові та молоці. При цьому зафіксовано підвищення активності ензимної ланки антиоксидантного захисту та зниження кількості соматичних клітин у молоці корів.

Ключові слова: корови, субклінічний мастит, соматичні клітини, окисна модифікація протеїнів, ліпосомальний препарат

Chepurna VA, Suprovych TM, Vishchur OI, Mizik VP, Solovodzinska IY. Influence of liposomal drug on the intensity of proteins oxide modification processes in subclinical mastitis of cows. Biol. Tvarin. 2021; 23 (2): 3-7. DOI: 10.15407/animbiol23.02.003. 